Conference Paper

\title{
Study on Online Purchase Decisions on The Online Shopee Selling Site
}

\author{
Ratna Herawati*, Amalia Nur Chasanah, Tito Aditya Perdana, Masitha Fahmi Wardhani \\ Faculty of Economics and Business, Dian Nuswantoro University, Indonesia
}

*Corresponding author:

E-mail: rathna.hiera@dsn.dinus.ac.id

\begin{abstract}
The state of the environment for consumers to get information, namely electronic word of mouth and the promotional mix will affect consumer decision-making when shopping. This study aims to determine the effect of promotional mix variables and electronic word of mouth on purchasing decisions on the online buying and selling site Shopee. Promotion mix variables used are advertising and sales promotion. The sample used in this study were Semarang residents who had shopped on the Shopee online buying and selling site with a sample size of 100 . The data analysis technique used was multiple regression with the classical assumptions of multicollinearity, autocorrelation, heteroscedasticity, and normality. The results showed that the variables of advertising, sales promotion, electronic word of mouth had a significant positive effect on online purchasing decisions. The adjusted $r$ square value is 0.496 , which means that the variables of advertising, sales promotion, and electronic word of mouth can explain online purchasing decisions by $49.6 \%$. In contrast, the rest is explained by other variables, not in this study.
\end{abstract}

Keywords: Purchase decisions online, advertising, sales promotion, electronic word of mouth

\section{Introduction}

According to APJII (Indonesian Internet Service Provider Association), consumers who shop online at the marketplace have reached 32 percent or around 84.3 million people. An increase of 3.79 percent, namely 11.6 million people from the previous year. Indonesian marketplace players welcomed this enthusiasm, and in 2018 more than 40 marketplace companies had been registered and operating in Indonesia. Currently, many companies provide sales of goods and services via the internet with their respective advantages, including Shopee, Tokopedia, Jd.id, Bukalapak, Blibli, Elevenia, Lazada, and so on. One of the most popular among netizens is Shopee. Although relatively new, Shopee already has approximately 60 million active users. Shopee continues to expand its market by aggressively promoting both from television media, online social media, and even collaborating with parties to make it more known in the wider community. Marketplace industry players are demand to be creative and innovative in marketing promotion strategies in the community, which are expected to influence the decision to buy company products. The purchase decision is a process so that consumers determine the product or service to be purchased.

According to Kotler and Armstrong (2010), the purchasing decision-making process itself starts from the introduction of information needs, information retrieval, evaluation of the information obtained, retrieval decisions, and finally post-trust behavior. Fulfillment of information sources about the marketplace before consumers shop, namely the majority through television advertisements, word of mouth, social media, and online advertisements.

Company imperative to provide and manage funds for marketing communications such as sales promotion, advertising, events and experience, public relations and publicity, direct and interactive marketing, salesforce, and word of mouth marketing (Kotler \& Keller, 2009). Word of mouth marketing can also be in the form of online and offline. Information that spreads by word of mouth is not limited to

How to cite:

Herawati, R., Chasanah, A. N., Perdana, T. A., \& Wardhani, M. F. (2021). Study on online purchase decisions on the online shopee selling site. $3^{\text {rd }}$ Economics, Business, and Government Challenges 2020. NST Proceedings. pages 13-19. doi: $10.11594 /$ nstp.2021.1303 
face-to-face communication, but e-wom can occur in the online form through social media called electronic word of mouth. E-wom is the opinion, information, or experience of product/service users who have used certain brands conveyed through online media (Hennig-Thurau et al. 2004).

The critical function of sales promotion in marketing communication is one of the company's work programs that can be felt directly by the community. The sales promotion programs are flexible, and the costs are not too high so that companies widely use them. The free shipping program became a very attractive promotional program at the beginning of Shopee's appearance. Other promotional programs from Shopee are product discounts, flash sales at specified times, games with prizes, as well as a free product giving for free for new users.

Based on the results of a survey conducted by the price team, in Q4 2019, Shopee was ranked first in the number of web visits, namely 72 million visitors and the most downloaded by Indonesians. However, in the first quarter of 2019, Shopee still lost to its two main competitors, namely Tokopedia and Bukalapak. Opening 2020 Q1 the number of Shopee web visitors fell from the previous period to 71 million visitors. This shows that electronic word of mouth, advertising programs, and popular Shopee sales promos are still not enough to gain the awareness of the Indonesian people. Such fluctuating conditions should be noted by Shopee separately.

Based on the background that has been previously stated, there is an increase in the number of marketplaces from year to year. This growth is significant because of its contribution to the income of the Indonesian people. However, if business people ignore advertising strategies, sales promotions, and other marketplace business players will rival consumer electronic word of mouth, the marketplace business age. Through this research, it is expected that there will be a good effect on the quality of advertising, sales promotion, electronic word of mouth that have an impact on consumer online purchasing decisions.

Based on the description above, the problem formulations in this study are:

1. Does advertising affect online purchasing decisions on the Shopee online buying and selling site?

2. Does sales promotion affect online purchasing decisions on the Shopee online buying and selling site?

3. Does electronic word of mouth affect online purchasing decisions on the Shopee online buying and selling site?

\section{Theoretical Basis \\ Buying decision}

Online purchasing decisions are consumer behavior in choosing products online from several alternatives to find solutions and give birth to decisions to use these products and make repeat purchases and recommend to others. Online Purchasing Decision Indicators are information retrieval, confidence in buying, repurchasing, recommending to others (Kotler and Amstrong, 2009).

\section{Advertisement}

Advertising is any form of non-personal presentation and promotion of ideas, goods or services by a specific sponsor which requires payment". In conclusion, advertising invites other people through media means to increase the purchase and introduction of a product/service. Where the ad must have a potential target audience so that there is a big possibility to make a purchase. Advertising indicators are ads that attract attention; advertising messages are clear and easy to understand, the importance of the benefits of advertising for consumers, directing action to buy (Kotler \& Keller, 2009).

Research conducted by Lailanur and Sulistyowati (2020) and Isyanahapsari and Nurseto (2018) shows that advertising has a positive effect on online purchasing decisions. Another study conducted by Siswina and Pramiyanti (2012) has different results which show that advertising has a negative influence on consumer purchasing decisions.

H1: Advertising has a positive effect on online purchasing decisions 


\section{Sales promotion}

Kotler and Armstrong (2010), sales promotion is an incentive given to encourage the purchase or sale of a product or service in a short period. To boost short-term sales and maintain good relationships with consumers, companies can achieve sales promotions. In conclusion, sales promotions are goods or services that consumers receive as an incentive from the seller to increase sales and market competitiveness. The sales promotion indicator, according to Kotler (2009), is easy to remember, has attractiveness, arouses shopping desire, encourages to make purchases.

Research conducted by Kevin et al. (2020) and Safitri and Niaga (2020) shows that sales promotions have a positive effect on online purchasing decisions. Another research conducted by Irawati (2018) has different results which show that sales promotions have a negative influence on online purchasing decisions.

$\mathrm{H} 2$ : Sales promotion has a positive effect on online purchasing decisions

\section{Electronic Word of Mouth (E-WOM)}

Electronic Word of Mouth (E-wom) is the opinion, information, or experience of product/service users who have used certain brands conveyed through online media (Hennig-Thurau et al., 2004). Electronic indicators of word of mouth, according to Sumangla and Panwar (2014) are Relevance, Timeliness, Accuracy, and Comprehensive.

Research conducted by Fatrina Dira et al. (2019) and Laiq (2020) shows that E-WOM has a positive effect on online purchasing decisions. Another study conducted by Wijaya and Eristia Paramita (2014) has different results which show that E-WOM has a negative influence on consumer purchasing decisions.

H3: Electronic Word of Mouth has a positive effect on online purchasing decisions

\section{Material and Methods}

The data analysis method used in this study is the multiple regression analysis. This is to determine the effect of advertising, sales promotion, and E-WOM on online purchasing decisions. This study uses multiple linear regression analysis by first testing the classical assumptions, namely the Multicollinearity, Heteroscedasticity, and Autocorrelation test and passing the Data Normality test.

\section{Population and sample}

The population in this study were all Shopee customers who bought online in Semarang. Sampling was carried out by non-random sampling method, namely accidental sampling, where customers who have made a purchase transaction at Shopee at least once are domiciled in Semarang.

\section{Results and Discussion}

Data normality

Table 1. Data normality

\begin{tabular}{ll} 
& Unstandardized Residual \\
\hline Kolmogorov-Smirnov Z & 0.047 \\
Asymp. Sig. (2-tailed) & 0.200 \\
\hline
\end{tabular}

Source: Data processed in 2020

From the output, it can be seen that the significance value is 0.200 above 0.05 , so it can be concluded that the data residuals have been normally distributed. 


\section{Classic assumptions}

Multicollinearity

From the output, it can be seen that all independent variables have a Tolerance value above 0.1 and a VIF value below 10 so that it can be concluded that the model is free from multicollinearity.

Table 2. Multicollinearity test

\begin{tabular}{llll}
\hline & Tolerance & \multicolumn{1}{c}{ VIF } & \multicolumn{1}{c}{ Information } \\
\hline Advertisement & 0.658 & 1.521 & There is no multicollinearity \\
Promotion & 0.605 & 1.652 & There is no multicollinearity \\
E-wom & 0.536 & 1.864 & There is no multicollinearity \\
\hline
\end{tabular}

Source: Data processed in 2020

\section{Autocorrelation}

Table 3. Autocorrelation test

Durbin-Watson

1.986

Source: Data processed in 2020

From the output, the Durbin Watson value is 1.986 with a dl value of 1.6086 and du of 1.7345 . Then the DW value is in the area between du and 4-du, so it can be concluded that the model is free from autocorrelation.

\section{Heteroscedasticity}

Table 4. Heteroscedasticity test

\begin{tabular}{lll}
\hline Variable & t & Sign \\
\hline Advertisement & 1,418 & 0,160 \\
Promotion & $-1,553$ & 0,124 \\
E-wom & 0,247 & 0,805 \\
\hline
\end{tabular}

Source: Data processed in 2020

Heteroscedasticity test using the Park test. From the output, it can be seen that the significance value of all independent variables is above 0.05 . Because the significance value is above 0.05 , it can be concluded that the model is free from heteroscedasticity.

ANOVA

Table 5. ANOVA

\begin{tabular}{llllll}
\hline & Sum of Squares & Df & Mean Square & F & Sig. \\
\hline Regression & 831,308 & 3 & 277,103 & 33,453 & 0,000 \\
Residual & 795,202 & 96 & 8,283 & & \\
Total & 1626,510 & 99 & & & \\
\hline
\end{tabular}

Source: Data processed in 2020 
From table 5, it can be seen that the model has a calculated $\mathrm{F}$ value of 33.453 and a significance of 0.000 . Because the significance value is below 0.05 , it can be concluded that simultaneously or together the advertising, promotion, and e-wom variables have a significant effect on purchasing decisions.

\section{Coefficient of Determination}

Table 6 Coefficient of determination

\begin{tabular}{lllll}
\hline Model & $\mathrm{R}$ & $\mathrm{R}$ Square & Adjusted R Square & Std. Error of the Estimate \\
\hline 1 & $.715^{\mathrm{a}}$ & .511 & .496 & 2.878
\end{tabular}

Source: Data processed in 2020

Based on table 6, it can be seen that the Adjusted R square value is 0.496 , which means that $49.6 \%$ of variations in purchasing decision variables can be explained by variations in the independent variables, namely advertising, promotions, and e-wom. In comparison, the remaining 50.4\% is explained by other variables, not in this study.

\section{Regression analysis}

After passing the classical assumption test, the following equation is obtained from the output:

Table 7. Regression results and hypothesis testing

\begin{tabular}{lllll}
\hline Variable & B & Std Error & T & Sign \\
\hline (Constant) & 2.056 & 1.929 & 1.066 & 0.289 \\
Advertisement & 0.221 & 0.091 & 2.419 & 0.017 \\
Promotion & 0.351 & 0.101 & 3.486 & 0.001 \\
E-wom & 0.334 & 0.103 & 3.253 & 0.002 \\
\hline
\end{tabular}

Source: Data processed in 2020

Equation:

Purchase Decision $=2,056$ ADS 0,221 PROMOTION 0,351 E-WOM 0,334

1. The constant 2.056 means that if the level of advertising, promotion, and e-wom is fixed or there is no change, the purchase decision is positive.

2. The advertising coefficient of 0.221 means that if the ad rate is frequently shown, while the other variables are constant, the purchasing decision will increase.

3. The promotion coefficient of 0.351 can be interpreted that if the level of promotion rises while other variables are constant, purchasing decisions will increase.

4. The E-wom coefficient of 0.334 means that if the level of e-wom increases while the other variables are constant, the purchasing decision will increase.

\section{Hypothesis testing}

Hypothesis 1 advertising affects online purchasing decisions

It can be seen from the results in table 8 that the coefficient value is 0.221 , with a significance level of 0.017. Because the significance value is below 0.05 , it can be concluded that Hypothesis 1 is accepted. In the advertising indicators that attract attention, the advertising message is clear and easy to understand, the importance of the benefits of advertising for consumers, and directs action to buy, the better the quality of the ad, the more influential the ad is in bringing consumer attention to further processing the information so that it helps consumers in making decisions to shop at Shopee. Consumers' understanding of the information contained in advertisements will help consumers get to know the products 
that Shopee offers. Shopee's knowledge from the advertisement influences the evaluation process until the purchase decision occurs. So, it can be concluded that there is an influence between advertising and consumer purchasing decisions. These results are following the findings of Adhy and Herieningsih (2019).

\section{Hypothesis 2 sales promotion affects online purchasing decisions}

It can be seen from the results in table 8 that the coefficient value is 0.351 , with a significance level of 0.001. Because the significance value is below 0.05 , it can be concluded that Hypothesis 2 is accepted. The indicators are easy to remember by knowing that there is a free shipping program, having an attraction to the Flashsale program, arousing the desire to shop on voucher and cashback programs, encouraging purchases due to sales promotions from Shopee in responding to consumer needs than elsewhere, it further influences decisions consumer purchases. So, it can be concluded that there is an influence between sales promotions and purchasing decisions. These results are consistent with the results of research by Adhy and Herieningsih (2019), and Rohmah (2018).

\section{Hypothesis 3 electronic word of mouth affects online purchasing decisions}

It can be seen from the results in table 8 that the coefficient value is 0.334 , with a significance level of 0.002. Because the significance value is below 0.05, it can be concluded that Hypothesis 3 is accepted. In the Electronic Word of Mouth indicator, how is the content of the message, updated information, correctness, and completeness of information in e-wom are useful in the decision-making process because consumers can be directly involved in information exchange activities about a product or brand. So, it can be concluded that there is an influence between electronic word of mouth and purchasing decisions. These results are following the research results of Aditya and Ariyanti (2019).

\section{Conclusion}

The conclusions of this study are:

1. Simultaneously, the three independent variables, namely advertising, sales promotion, and electronic word of mouth, have a significant effect on online purchasing decisions.

2. Partially, advertising, sales promotion, and e-wom variables have a significant effect on purchasing decisions. The variable that has the most significant influence is the sales promotion variable.

Regression has a coefficient of determination of 0.511 or $51.1 \%$. Variations in online purchasing decision variables can explain variations in advertising, sales promotion, and e-wom variables, while other variables explain the rest.

\section{References}

Adhy, M. A. R. S., \& Herieningsih, S. W. (2019). Pengaruh terpaan iklan bukalapak di televisi dan promosi penjualan terhadap keputusan pembelian di situs jual beli online Bukalapak. Interaksi Online, 7(4), 105-112.

Aditya, A., \& Ariyanti. (2018). Pengaruh Electronic Word of Mouth (eWOM) terhadap keputusan pembelian masyarakat Bandung di Shopee. International Journal of Computer Applications, 6(3), 5566-5583.

Fatrina, D., Kamil, I., \& Hasan, A. (2020). Pengaruh Live-Chat dan E-WOM terhadap pengambilan keputusan transaksi online pada matketplace e-commerce. Jurnal Nasional Teknologi Dan Sistem Informasi, 5(3), 121-129. https://doi.org/10.25077/teknosi.v5i3.2019.121-129

Hennig-Thurau, T., Gwinner, K. P., Walsh, G., \& Gremler, D. D. (2004). Electronic word-of-mouth via consumer-opinion platforms: What motivates consumers to articulate themselves on the Internet? Journal of Interactive Marketing, 18(1), 38-52. https://doi.org/10.1002/dir.10073

Irawati, P. C. M. (2018). Pengaruh promosi online dan kualitas pelayanan terhadap keputusan pembelian konsumen. Skripsi. Fakultas Ekonomi Universitas Sanata Dharma Yogyakarta.

Isyanahapsari, S., \& Nurseto, S. (2018). Pengaruh periklanan dan kualitas pelayanan terhadap keputusan pembelian secara online pada situs belanja online (Studi kasus pada pengguna e-commerce elevenia di Kota Semarang). Jurnal Ilmu Administrasi Bisnis, 7(1), 117-129. 
Kevin, A.M., Widad, A., \& Nofiawaty, N. (2020). Pengaruh periklanan dan promosi penjualan aplikasi grabfood terhadap keputusan pembelian konsumen (Studi pada Mahasiswa Fakultas Ekonomi Jurusan Manajemen Universitas Sriwijaya Kampus Bukit Palembang) (Doctoral dissertation, Sriwijaya University).

Kotler, P., \& Armstrong, G. (2010). Prinsip-prinsip pemasaran, Jilid 1 dan 2 Edisi Kedua Belas. Jakarta: Erlangga.

Kotler, P., \& Keller, K. L. (2009). Manajemen Pemasaran (terj). Hendra Teguh, Benyamin Molan dan Rony A. Rusli. Jilid, 2.

Lailanur, I. H., \& Sulistyowati, R. (2020). Pengaruh brand ambassador dan iklan terhadap keputusan pembelian konsumen pada marketplace Tokopedia. Jurnal Pendidikan Tata Niaga (JPTN), 8(3), 1-10.

Laiq. A. (2020). Pengaruh promosi dan electronic word of mouth terhadap keputusan pembelian. September.

Rohmah, M. (2018). Pengaruh promosi penjualan terhadap keputusan pembelian konsumen pada situs jual beli online Elevenia. JOM FISIP, 5.

Safitri, D. D., \& Niaga, P. T. (2020). Keputusan pembelian produk kecantikan di online marketplace ( studi pada konsumen di surabaya ), 8(3), $1020-1026$.

Siswina, S. I., \& Pramiyanti. (2020). Pengaruh iklan online terhadap keputusan pembelian produk pakaian wanita caramelloo shop: analisis terhadap efektivitas penggunaan iklan media sosial pada facebook, twitter dan blackberry messenger.

Sumangla, R., \& Panwar, A. (2014). Capturing, analyzing, and word of mouth in digital marketplace.

Wijaya, T., \& Paramita, E. L. (2014). Pengaruh Electronic Word of Mouth (E-WoM) terhadap keputusan pembelian kamera DSLR. Seminar Nasional Dan Call for Paper, 978-602-70429-1-9, 12-19. 